\title{
Anxiety and Depression among Guardian Grandparents: A Proposal for a Psychoeducational Intervention
}

\author{
Cristina Maria de Souza Brito Dias, Celia Maria Souto Maior de Souza Fonseca, \\ Cirlene Francisca Sales da Silva, Emily Schuler, Jhérsyka Evelin Mendes Lins
}

Universidade Católica de Pernambuco (UNICAP), Recife, Brazil

Email: schuler.mily@gmail.com

How to cite this paper: de Souza Brito Dias, C. M., de Souza Fonseca, C. M. S. M., da Silva, C. F. S., Schuler, E., \& Lins, J. E. M. (2016). Anxiety and Depression among Guardian Grandparents: A Proposal for a Psychoeducational Intervention. Psychology, 7, 1486-1502.

http://dx.doi.org/10.4236/psych.2016.713146

Received: September 8, 2016

Accepted: November 5, 2016

Published: November 8, 2016

Copyright $\odot 2016$ by authors and Scientific Research Publishing Inc. This work is licensed under the Creative Commons Attribution-NonCommercial International License (CC BY-NC 4.0).

http://creativecommons.org/licenses/by-nc/4.0/

\begin{abstract}
It is known that raising children is the responsibility of parents. However, several factors of an economic, relational and work have led grandparents to actively participate in the creation of grandchildren. Research has shown that for many grandparents, the fact of raising their grandchildren causes several difficulties to physical and psychological level, among which we highlight increased anxiety and depression. This study therefore aimed to design, implement and evaluate the effects of a psychoeducational intervention aimed at alleviating anxiety and depression of grandparents caring for grandchildren. 55 grandparents with an average age of 64 years participated in this research. They underwent a sociodemographic questionnaire, application BAI and BDI, before and after a psychoeducational intervention, and an interview to evaluate the intervention. This comprised eight sessions held weekly in groups, lasting two and a half hours. After analyzing the results, it can be seen that the grandparents reduced the level of depression and anxiety. This experience led to observe, through appearance, ease and own lines of grandparents; the intervention consisted in beneficial space so that they can better deal with the raising of grandchildren.
\end{abstract}

\section{Keywords}

Grandparents, Grandchildren, Anxiety, Depression

\section{Introduction}

Aratangy and Posternak (2010: p. 21) state that the 21st century will be "the century of grandparents" and reveal international data with significant numbers; such as among Americans, more than half become grandparents between the age of 49 and 53- 
spending 30 to 40 years in this role. In France, $80 \%$ of people over 65 years have grandchildren, and almost half are going to be great-grandparents. Some will be greatgreat-grandparents encountering $20 \%$ of women over 80 who are great-great-grandmothers. In England, there are now 16.5 million grandparents by the age of 54; half of the population has grandchildren. Of these, $25 \%$ are primarily responsible for taking care of their grandchildren, spending an average of six and a half hours per week as parental substitutes.

In Brazil, by the year of 2006, the Brazilian Institute of Geography and Statistics (IBGE), recorded 1.7 million grandchildren and great-grandchildren living in the home of grandparents and great-grandparents over the age of 65, with or without the presence of parents. Those who care for grandchildren alone totaled 466,000, and the number of grandchildren and great-grandchildren was 690,000. Projections wave greater numbers than the ones drawn. In this regard the said institute (IBGE, 2010) affirms that in the last 10 years, the number of children has been reduced and the elderly in the country increased. According to its estimates, in 2020, Brazil will be the sixth country with more elderly in the world. The organ, quoted above, points out that the increase in life expectancy, coupled with the drop in fertility rates has contributed that current families have more grandparents living with grandchildren.

Morgado and Vitorino (2012) confirm that there was never, as now, so many grandparents to so few grandchildren and punctuate that this trend should remain or become more acute due to projections that soon Western societies will have more elderly than children and young people, leaving the renewal of generations behind. Cardoso and Brito (2014: p. 438) argue "as life expectancy in the past was much less, there were many families with three generations living together". These authors cite Attias-Donfut and Segalen (2001) who consider experiencing a unique moment with regard to the role of grandparents.

It is important to consider that grandparents are essential in the lives of their grandchildren. Triadó et al. (2000) support that generational approach, between grandparents and grandchildren, puts grandparents as a central element within this broad system resulting benefits in the relationship with their grandchildren and vice versa, deriving from this meeting a healthy exchange of affection, mutual care and help in the economic field.

Cardoso (2011) suggests that by becoming grandmother earlier and because of longevity, there is the possibility of greater interaction between the generations, which caused changes in intergenerational ties. Thus, the author continues, grandparents help in shaping the character of grandchildren, offering elements that facilitate socialization as well as relationships. They are seen as integral members of the family network that give an emotional and instrumental support, not only to their grandchildren, but also to their children.

In recent years, the growing attention to the phenomenon of grandparents raising their grandchildren can be seen (Morgado \& Vitorino, 2012). Newspapers, popular magazine articles and scientific theses and dissertations, report that it increasingly 
common for grandparents to become the primary caregivers of their grandchildren due to the significant increase in social problems, such as grandparents who came to replace deceased parents, unprepared teenagers or immature adults, drug addicts, abusers, people with mental and physical disorders (as for instance AIDS), neglect, abandonment and divorce of parents (Dias, Costa, \& Rangel, 2005; Mainetti \& Wanderbroocke, 2013; Pebley \& Rudkin, 1999). According to the authors, the results of several studies are consistent with the idea that grandparents often take on parental roles in relation to their grandchildren only when their own children are having problems that hinder their parental responsibilities.

In previous research, which investigated the perceptions and feelings of grandparents raising their grandchildren (Dias, Costa, \& Rangel, 2005; Dias \& Costa, 2006) and the relations between the different generations of the family living under the same roof (Dias, Ataide, Albuquerque, \& Magalhães, 2011), we observed how the grandparents feel overwhelmed and stressed because they are taking care of children and grandchildren. When grandparents assume the functions of parents may occur experiences and feelings such as anger, fear, guilt and depression. In general, they experience dissatisfaction for being in the situation of having to take care of the new generations, at a time when they would like to enjoy freedom and autonomy to resume or start old life projects or simply rest.

Older people are considered rooted in the past, while the younger's efforts are aimed at the future. Therefore, it appears that taking care of grandchildren is a mixed situation of ambivalent feelings; it can bring many joys, but may cause many physical and emotional tasks for the elderly that may be harmful. In addition, other factors such as age (both grandmothers and grandchildren), marital status, unresolved conflicts with the second generation, economic situation, among others, contribute decisively to the quality of the relationship between grandparents, parents and grandchildren (Dias \& Costa, 2006). The care for the grandchildren tends to fall on grandmothers, being this study directly focused on them.

The studies of Williamson, Sofas-Hall \& Miller (2003) suggest that support groups may be made for those grandparents with educational materials and seminars in schools and other institutions, to help them cope with stressful situations that generate emotional negative reactions, in addition to seeking a better relationship between grandparents and grandchildren, and offer useful knowledge so that they respond better to family situations. In this sense, psychoeducational intervention is a type of group work that combines psychological and educational knowledge about a particular subject. The main focus is to discuss psychological issues for the development of skills and coping strategies facing a certain difficulty. Its goals are educational, of prevention and promotion of psychological health (Lopes \& Cachioni, 2013). Therefore, this research has the general objective of developing, implementing and evaluating the effects of a psychoeducational intervention, aimed at alleviating anxiety and depression of grandmothers who care for their grandchildren.

This study is justified due to the increasing contingent of grandmothers who, for 
various reasons, take care of their grandchildren. Despite being a theme with so far poor visibility, the study of this phenomenon is very important to understand both generations.

\section{The Difficulties and Benefits of Caring for Grandchildren}

There are different ways to name grandparents raising grandchildren as: substitute parents, parents in absentia, reserve parents, guardian grandparents, fulltime grandparents, grandparents with custody (when they get legal custody of the grandchild). In this project, they are appointed as guardian grandparents (Dias, Costa, \& Rangel, 2005). The corresponding phenomenon is defined as reparentification (Williamson, Softas-Nall, \& Miller, 2003).

Taking care of grandchildren can be a pleasant task for grandparents. As explained by Oliveira (1993), some perceive coexistence with the grandchildren as favorable, a source of renewal and interest in life, pride, satisfaction, a sense of usefulness and trust, as well as fun in sharing games and activities with grandchildren. The author concludes that the grandparents educate and at the same time they are re-educated by the children, since they are forced to relive situations that end up leading them to new experiences and habits. They are renewed as subjects in this interaction.

Cardoso (2011) also states that coexistence between grandparents and grandchildren allows a close emotional relationship that is beneficial to both. For Attala (1996), the child's presence can cause greater unity in family and couple. In other studies, some grandparents also reported that after the arrival of grandchildren they were enjoying more health and leading a more active life (Grinstead, Leder, Jensen, \& Bond, 2003).

Other authors, however, agree that to take care of grandchildren can generate various difficulties for the grandparents, such as stress; depression; health decline demonstrated in physical complaints; economic problems; concerns with the education and discipline of grandchildren; and confusion of roles, since they assume the role of parents and grandparents at the same time. In addition, they may develop feelings of shame, loss, guilt and grief over the children that have left them in this situation. Another factor that should be taken into consideration is the health of grandparents who often suffer because they fail to take care of themselves to meet the needs of grandchildren. Even the stress they feel may end up harming their health. They also fear that the grandchildren develop the same problems that parents, like drug abuse, for example (Fitzgerald, 2001; Kelley, Whitley, Sipe, \& Yorker, 2000; Orb \& Davey, 2005; Williamson et al., 2003).

Mayer (2002) adds that the care of grandchildren brings pressures, often unexpected, because in addition to the care of the grandchildren, there are also emotional needs, legal issues, financial difficulties and problems of transition to become caregivers.

Jendrek (1994) explains the damage to health by the fact that the care of grandchildren matches their natural physical decline due to age. The demands that a small child requires (stooping, play, bathe) and the difficulty to discipline the older grandchildren, can lead them to develop heart problems. Morales (2001) came to draw up the so-called "grandmother slave syndrome" that affects women with a strong sense of order, digni- 
ty, responsibility and modesty and assume their tasks with pleasure. But with time and the accumulation of roles (housewife, daughter, wife, mother and grandmother), end up wearing out, thus developing various symptoms, including anxiety and depression, and come to a natural death or even suicide.

According to Grinstead et al. (2003) some grandparents report no differences in relation to health with the arrival of grandchildren; others feel an improvement, and, finally, several reported that there was damage to their health as a result of the various roles and pressures they face. Cardoso and Brito (2014) punctuate that cooperation between parents and grandparents is usually voluntary and beneficial, but may result in a requirement for grandparents, who, with these activities, feel physical and mental exhaustion.

The causes of depression in advanced age are often attributed to stressful events (Stuart-Hamilton, 2002). Heywood (1999) and Williamson et al. (2003) found the incidence of depression in grandparents within feelings that they have failed as mothers, experienced conflicts with their children and concerned with the welfare of their grandchildren. There are other factors that favor the development of depression, for example, some turn away from society on the basis of various household tasks. Failure to develop social activities and the fear that there is no one to care for their grandchildren in their absence are also elements that predispose to depression. Furthermore, it should be pointed out the danger of depression interact with its cause, so installing a vicious cycle: the grandmother is depressed due to family conflicts, but her depression further worsens the relationship, which increases depression, and so on (StuartHamilton, 2002). According to Musil and Ahmad (2002), depression and anxiety reach higher levels in grandparent caregivers of grandchildren than in non-caregiving grandparents.

Researchers who have investigated the subject did not reach a consensus about the impact of this experience for grandparents. While some say they are proud and happy to raise their grandchildren, because they feel useful and renewed by this conviviality, others refer to overload the damage caused to physical and mental health, as well as feelings of anger, hurt and resentment against the children they left in such a situation. Mayer (2002) states that, due to the emotional results that the care of grandchildren can generate, it becomes clear that these grandparents need assistance.

This research therefore had as general objective to design, implement and evaluate the effects of a psychoeducational intervention aimed at alleviating anxiety and depression of grandparents who care for grandchildren. Specifically sought: to identify the presence of anxiety and depression in these women; evaluate the effects of psychoeducational intervention comparing the indicators of anxiety and depression before and after the intervention; and analyze impressions of grandmothers about the intervention.

\section{Method}

\subsection{Participants}

Participated in all sessions of the psychoeducational intervention 55 grandmothers, 
aged between 42 - 73 years (mean age of 64 years), most of them were married, their educational level varied from elementary school to university level, and all of them cared fulltime or part time for all their grandchildren. They lived in outlying neighborhoods of Recife and took care of one to six grandchildren. These guardian grandmothers had the score of at least "light" in the Beck Anxiety Inventory (BAI) and/or Beck Depression Inventory (BDI).

In all, there were contacted and evaluated more grandmothers, but some failed to participate due to personal difficulties (going to doctors, not having anyone to leave family, previous commitments). Others have not had the results computed for not presenting results indicators of anxiety and/or depression, or having more than two absences in the intervention (cutoff point), although they continued in the intervention.

\subsection{Instruments Used}

1) Socio-Demographic Data Questionnaire-with questions such as age, education, marital status, religion, profession, income, number and sex of children, number of grandchildren that are cared by her, reason that led her to care for the grandchildren, sex and age of these grandchildren, as well as the health conditions of this grandmother, with whom she lives and a contact phone.

2) Beck Anxiety Inventory (BAI) - composed of 21 items, each presenting four formulations that reflect increasing severity levels of each of the symptoms of anxiety (Goreinstein \& Andrade, 1998). The validation study of the Portuguese version of the Beck Anxiety Inventory (BAI) was made by Quintão, Delgado and Prietro (2013) pointing out the reliability of the instrument to measure anxiety with good psychometric quality.

3) Beck Depression Inventory (BDI) - consists of 21 items, each with four alternatives reflecting increasing degrees of severity in depression (Cunha, 2001). The items refer to sadness, pessimism, sense of failure, dissatisfaction, punishment, suicidal ideas, crying, irritability, social withdrawal, indecisiveness, change in self image, difficulty in working, insomnia, fatigue, loss of weight, somatic concern and sexual desire. According to Baptista, Souza and Alves (2008) several psychometric studies have been made with Brazilian samples pointing out the reliability of the instrument.

4) Psychoeducational Intervention-consists of eight sessions, held weekly, lasting two and a half hours each, covering various subjects of interest of the grandmothers, as described in the results section. The themes discussed in the intervention were based on the current proposal for grandparents elaborated by Strom and Strom (Strom \& Strom, 1987; Strom, 1988; Strom \& Strom, 1993). Although, the dynamics used during the intervention were created by the team.

5) At the end of the intervention a semi-structured interview was used in order to obtain an evaluation by the grandmothers of the experimental group. They contained the following questions: a) How do you feel participating in the group? b) What subjects or topics most touched you? c) What did you do before in relation to your grandchild that you do not intend to do anymore? d) What aspect or part of the process was 
more important to you? Why? e) What do you think about your future actions: i) in relation to your grandchild; ii) in relation to his or her parents; iii) in the relationship with your husband; iv) in the relationship with other family members; v) Would you like to add something more about your experience?

\subsection{Data Collection Procedure}

First, the study was approved by the Scientific and Ethics Committee of the university that supported the research with the following report number: CEP No. 14/2010 and CAEE 0011.0.096.000-10. The participating grandmothers were recruited from communities in the outskirts of Recife, having made five groups, which were welcome in a room dedicated to groups, of the university's clinic. It was explained to them the purpose of the survey, at which time it was requested permission to them to take part of it. After reading, they signed the consent form. Once given such permission, each was met individually and answered the first three instruments. After inventories were corrected, grandmothers were selected that had the score of the BAI and/or BDI at least at a light' level or above to participate in the research.

\subsection{Procedure of Data Analysis}

For the data analysis of the quantitative part of the study, was built a database in Microsoft Excel spreadsheet, which was exported to SPSS, version 12, where the analysis was performed. To assess the degree of depression of the elderly before and after the completion of the psychoeducational intervention we calculated the mean and standard deviation of the BAI and BDI scores. To assess the normality of scores used in the study was applied the Kolmogorov-Smirnov test and where the test showed normal T-student test compared to the average depression score before and after implementation of the intervention was applied. Still, the grandparents were classified according to the degrees of minimum, light, moderate and severe depression and anxiety, through the score obtained in BAI and BDI. Comparing the distribution of classification of BAI and BDI, before and after the psychoeducational intervention Qui-square test for homogeneity was applied. All conclusions were drawn considering the significance level of $5 \%$.

The data obtained in the qualitative part of the intervention, were analyzed according to the technic of Thematic Content Analysis (Minayo, 2004).

\section{Results}

The data collected with the sociodemographic information from the grandmothers are displayed in Table 1, to give the reader a better understanding about the profile of the research participants.

\subsection{Results of the BAI and BDI Inventories before and after the Intervention}

The group with the highest average of anxiety and depression prior to the intervention, both BAI and BDI, was the group called number 2 (mean $=26.9$ and 18.1, respectively). 
Table 1. Sociodemographic data from the participant grandmothers.

\begin{tabular}{|c|c|}
\hline Marital Status & Quantity of grandmothers \\
\hline Married & 28 \\
\hline Divorced & 8 \\
\hline Widow & 9 \\
\hline Single & 10 \\
\hline Ages & Quantity of grandmothers \\
\hline $36-60$ & 27 \\
\hline $61-75$ & 23 \\
\hline $76-86$ & 5 \\
\hline Quantity of grandchidren she takes care of & Quantity of grandmothers \\
\hline $1-2$ & 45 \\
\hline $3-6$ & 10 \\
\hline Time she stays with the grandchildren & Quantity of grandmothers \\
\hline The whole day & 38 \\
\hline At least one shift & 17 \\
\hline Education & Quantity of grandmothers \\
\hline Alphabetized & 45 \\
\hline Illiterate & 4 \\
\hline Not identified & 6 \\
\hline Occupation & Quantity of grandmothers \\
\hline Retired & 8 \\
\hline Waste picker & 1 \\
\hline Merchant & 3 \\
\hline Seamstress & 2 \\
\hline Cook & 2 \\
\hline Diarist & 2 \\
\hline Housewife & 34 \\
\hline Housemaid & 3 \\
\hline Religion & Quantity of grandmothers \\
\hline Catholic & 10 \\
\hline Spiritist & 1 \\
\hline Protestant & 44 \\
\hline Total of validated grandmothers & Quantity of grandmothers \\
\hline Grandmothers & 55 \\
\hline
\end{tabular}

The scores were followed by the group number 1 (mean $=23.2$ and 16.0 , respectively) and the group number 4 (mean $=18.5$ and 14.5 , respectively). Still, the group with the lowest mean score of anxiety in the BAI was group 5 (mean $=8.2$ ). In the BDI with the lowest score was the group number 3 (mean $=9.3$ ). Upon completion of the intervention group 2 remained the group with the highest BAI score average $($ mean $=16.7)$ and 
BDI (mean = 12.3). When assessing the mean comparison test, it is observed that, for the BAI, it was significant in all the groups, except in groups 4 and 5 ( $p$-value $=0.076$ and 0.127 , respectively) indicating that the average score of these groups after the intervention, did not show a significant difference from the baseline. As for the BDI, the test was significant only in groups 1 and 5 ( $p=0.016$ and 0.018 , respectively), indicating that in both groups there is a difference in the average score of depression after the application of the intervention. Overall, the BAI and BDI test showed a reduction in mean score after application of the intervention (19.0 to 12.25 in BAI and 13.9 to 10.4 in BDI). Furthermore, comparison of means test was significant in both tests $(p<0.001$ and 0.002, respectively). The means of the BAI and BDI are shown in Table 2.

According to Table 3 it appears that before the intervention 41.8\% (23 grandparents) had moderate to severe score in the BAI and after the intervention this prevalence dropped to $16.3 \%$ ( 9 grandparents). Moreover, the distribution comparison test was significant $(p$-value $=0.020)$ indicating that the rating distribution of the BAI scores before and after the procedure is different.

Through Table 4 it appears that, before the intervention, 23.6\% (12 grandparents) had moderate score of the BDI and after the intervention this prevalence dropped to 9.1\% (5 grandparents). Moreover, it is noted that even though presented a reasonable

Table 2. Means and standard deviations of the BAI and BDI scores evaluated according to study group.

\begin{tabular}{ccccccc}
\hline \multirow{2}{*}{$\begin{array}{c}\text { Group } \\
\text { evaluated }\end{array}$} & \multicolumn{3}{c}{ BAI } & \multicolumn{3}{c}{ BDI } \\
\cline { 2 - 7 } & Test & Retest & $p$-value & Test & Retest & $p$-value \\
\hline 1 & $23.2 \pm 9.9$ & $14.1 \pm 7.2$ & 0.002 & $16.0 \pm 9.0$ & $8.0 \pm 5.6$ & 0.016 \\
2 & $26.9 \pm 10.5$ & $16.7 \pm 7.8$ & 0.006 & $18.1 \pm 9.8$ & $12.3 \pm 6.9$ & 0.074 \\
3 & $16.8 \pm 11.0$ & $12.3 \pm 11.1$ & 0.042 & $9.3 \pm 7.8$ & $10.3 \pm 6.3$ & 0.523 \\
4 & $18.5 \pm 10.5$ & $10.4 \pm 7.1$ & 0.076 & $14.5 \pm 7.7$ & $11.5 \pm 5.0$ & 0.151 \\
5 & $8.2 \pm 3.3$ & $5.9 \pm 3.4$ & 0.127 & $12.9 \pm 6.4$ & $8.7 \pm 3.6$ & 0.018 \\
General & $19.0 \pm 11.3$ & $12.25 \pm 8.7$ & $<0.001$ & $13.9 \pm 8.7$ & $10.4 \pm 5.8$ & 0.002 \\
$p$-value & $<0.001$ & 0.037 & - & 0.079 & 0.422 & - \\
\hline
\end{tabular}

${ }^{1} p$-value of the T-Student test to compare means for paired samples. ${ }^{2} p$-value ANOVA test.

Table 3. Distribution of guardian grandparents evaluated on the BAI classification according to the time of collection.

\begin{tabular}{cccc}
\hline & \multicolumn{2}{c}{ Time of Collection } & \\
\cline { 2 - 3 } BAI Classification & $\begin{array}{c}\text { Before the } \\
\text { Intervention }\end{array}$ & $\begin{array}{c}\text { After the } \\
\text { Intervention }\end{array}$ & -value $^{\mathbf{1}}$ \\
\hline Minimum $(0-10)$ & $14(25.5 \%)$ & $24(43.7 \%)$ & \\
Light $(11-19)$ & $18(32.7 \%)$ & $22(40.0 \%)$ & 0.020 \\
Moderate $(20-30)$ & $14(25.5 \%)$ & $7(12.7 \%)$ & \\
Severe $(31-63)$ & $9(16.3 \%)$ & $2(3.6 \%)$ & \\
\hline
\end{tabular}

${ }^{1} p$-value of qui-square test for homogeneity. 
Table 4. Distribution of guardians grandparents evaluated on the BDI classification according to the time of collection.

\begin{tabular}{cccc}
\hline & \multicolumn{2}{c}{ Time of Collection } & \\
\cline { 2 - 3 } BDI Classification & $\begin{array}{c}\text { Before the } \\
\text { Intervention }\end{array}$ & $\begin{array}{c}\text { After the } \\
\text { Intervention }\end{array}$ & -value $^{\mathbf{1}}$ \\
\hline Minimum $(0-11)$ & $20(36.4 \%)$ & $31(56.4 \%)$ & \\
Light $(12-19)$ & $22(40.0 \%)$ & $19(34.5 \%)$ & 0.065 \\
Moderate $(20-35)$ & $12(23.6 \%)$ & $5(9.1 \%)$ & \\
\hline
\end{tabular}

${ }^{1} p$-value of qui-square test for homogeneity.

reduction in the prevalence of patients with moderate BDI after applying the intervention, the distribution comparison test was not significant $(p$-value $=0.065)$ indicating that the rating distribution before and after the procedure is identical. Note that the $p$-value was very close to significance indicating that there is a trend of decreasing prevalence of moderate BDI after the realization of the intervention.

\subsection{Results of the Psychoeducational Intervention}

The psychoeducational intervention was made up of eight sessions, namely:

\section{1st session: Presentation, calendar of interests and needs, framing:}

After filling the socio-demographic data and the application of inventories, the purpose of this first session was to know the participants and they know each other, facilitating the group integration. We used the dynamics of the colored paper (Lucchiari, 1999) in which cut colored papers were distributed among all group members, two of each color. The grandparents then had to find out who had the same color of paper and sit with that person. Then they made for their partner the following questions: 1) what do you like to do? 2) What you do not like to do? 3) What is your biggest dream? Then they presented their partner to the group. In this first session they are asked about the feelings experienced whilst caring for the grandchildren, the expectations facing the group and the frame was made (days, hours, room, need for secrecy, not miss, among others). Here are some lines that portray the feelings and concerns of grandparents about the situation of raising grandchildren:

"My concern is my grandson. He is now six years old and from time to time he says that I am not his mother, especially when I fight with him."

"I have an eight year old grandson and sometimes I feel a little suffocated. I love very much my grandson, but sometimes it suffocates me."

"I was very interested to learn more, because P $m$ having trouble with my granddaughter. I think 1 m more worried about her than her mother."

The statements above confirm what was explained by the authors referred to ambivalence of feelings experienced by grandparents raising grandchildren (Dias, Costa, \& Rangel, 2005).

2nd session: Development of children:

The second session aims to make available a greater knowledge of child development 
and the consequences of actions taken by their caregivers may have in their future. First, an expository presentation of the themes was made with the following themes: child development, school development, sibling rivalry, aggression, need to play, and setting limits.

After this exposure, there was made the dynamics of crumpled paper. To every grandmother was given a piece of paper, and asked that they knead the paper with their hands every time they listen to a word or negative phrase, spoken by the facilitator (Ex: "You just give me work to do"; "I'm tired of you"). Then it was asked that they opened the paper and leave it as smooth as before. After a few minutes of insistence, the participants compared the kneaded with a plain paper, and realized that it did not return to be like before. They reflected thus on the lasting consequences of pernicious pedagogy.

Then another paper was given to the participants. First, it was suggested that all swung the sheet of paper, which caused a great noise; then was asked them to knead the page whenever you listen to the words or phrases now of positive nature from the facilitator (ex: "I love you", "You just gives me joy"). When asked them to sway the sheet of paper again, and it no longer does the noise before, but a soft noise. It was reflected this time about education and discipline given properly. It is noteworthy that at the meetings held after the application of this dynamic some grandparents commented that they made it at home with their families and holding crumpled paper to always remember what they have learned in this session. Two statements illustrate what they said:

"I learned today in a few minutes on the paper. Because I am in this picture... and this is where I have to change. I am often explosive and then get sick because I spoke that way. And I have to do differently... use sweet words."

"Because after it hurts it does not return. So you have to give love. I'll take it for life. It was great!"

\section{3rd session: Adolescent development:}

Knowledge of adolescent development is fundamental for a better understanding of this moment of transition of the human being. That is the goal of the third session. Initially information is given about puberty and adolescence; the adolescent's needs to belong to a group, their quest for autonomy and consolidation of their identity and the importance of not judging the appearance.

After this presentation, there is a dynamic with the group, where the facilitator showed grandmas two boxes, one handsome and another with an old and unkept appearance. Then was asked to the participants which box kept itself the best content. After listening to the opinions, the facilitator opened the boxes revealing that the most beautiful box kept trash, while the ugly box contained sweets and chocolates. It was established then a reflection on the possible inconsistency between the internal and external content and the need not to judge by appearances. In this session a few grandparents chose the messed up box as the bearer of ugly objects (commented on the possibility of having mice and other disgusting creatures within it), others, however, acknowledged that the ugly appearance of the box could not match its contain. One speaks of this session: 
"I learned today that certain things are part of adolescence. So I'm going peaceful home with my boy."

\section{4th session: Communication strategies:}

The goal of the fourth session is that grandmothers attempt to problems arising from poor communication. Initially, it was made the dynamic of "telephone" where a grandmother was asked to speak one sentence to another, without the others listen, until the phrase came to the last person. When this one pronounced the sentence it was considerably different from that spoken by the facilitator to the first grandmother. Then a lecture was given addressing the theme family communication and strategies were presented to improve communication as listening while the other speaks; not repeat arguments or discussions that have no effect; not to attribute feelings of the sender to the receiver of the message; not talk while you're nervous, among others. Thus, it was reflected on the possible failures in communication and its impact on relationships. Here are some phrases related to this topic:

"Today was good for us to think before you speak!"

"I learned a lot how to get to that point we' re wanting. Now I will talk to my granddaughter differently, I am going to reflect more."

\section{5th session: Conflict resolution strategies:}

The purpose of this session is to introduce strategies to deal with the stresses of raising grandchildren and other conflicts, especially in the family. Most often, conflicts are the result of several moments of tension or misunderstandings that are not properly resolved. In this session, strategies were discussed that people can adopt thinking that will minimize or avoid conflicts such as dodge; coercing another; create expectations that the situation will resolve itself; adopting extreme reactions that do not solve, among others. The dynamic used was the following: grandmother was asked to (voluntarily) simulate a conflict resolution between her and her teenaged granddaughter, represented by a member of the team. After the performance, the participants discussed what the grandmother could have done so that the resolution would be more effective.

"I wonder what will be the situation of these children (her grandchildren). Sometimes one says "I'm going to live with daddy because you are too boring". Then... I talk to him and after a while he comes, says he loves me and everything is all right. But $1 \mathrm{~m}$ worried... because I do not really know how to talk."

"Father is father and mother's mother, isn't it? We create the boys, but mother and father have to always have a special place in your child s heart."

The statements exemplify the difficulty that grandparents face in raising their grandchildren because of parental interference as had been reported by Fitzgerald (2001). Also transpire the difficulties and confusion of their own grandchildren living with the situation to be raised by grandparents (Orb \& Davey, 2005).

\section{6th session: Family relationship:}

The sixth session aims to ratify the importance of family relationships, commenting strategies to improve them, as well as meet the demands brought by grandmothers during the first six meetings. Initially, there was a lecture about the family and the pe- 
culiarities of the various roles that one person has in the same family, especially in the case of guardian grandparents. For the dynamic were used two dolls, a boy and a girl, especially made for this research. It was given the opportunity to anyone who would like to speak to them, pretending it was someone from their family to whom they always wanted to say something and had no opportunity or courage. Many participants cried during this dynamic and verbalized old hurts, guilt, misunderstandings, as well as expressions of affection for family members to whom they have never had the courage to verbalize.

"I would like to talk to my grandson for him to be a person closer to me. I beg a lot that he listens to me."

"I see now that she's not the girl that I was. I was rebellious! And I charge her things I did not give my mother!"

"Today was to enrich more, touched more... especially today."

7th session: Health care, senior citizen laws and demands that arise during the intervention:

The focus of the seventh session is the physical and psychological well being of grandmothers. The goal is to make them aware of their rights (based on the Elderly Laws of the Brazilian country) and sources of support. In the lecture, the rights of the elderly were presented and how the participants should do if these rights are denied them in some way. In addition, there was a talk about the common diseases of the elderly, how to prevent them and where to get help, if they do have symptoms. Strategies were explained them to achieve an active aging. Information was also provided to the grandparents about the health of their grandchildren, and the importance of vaccination, care for hygiene and where to seek medical and psychological support, if necessary. All participants received an information booklet, developed by the team, with the information presented in the session, together with major phone numbers.

"I worry about my health. So I think until when will I be able to be taking care of them (grandchildren)."

This speech is representative of the losses that the overweight of raising grandchildren may inflict to grandparents. While they feel responsible for their grandchildren, grandmothers tend to neglect their health because they are spending their time and resources in raising and caring for them. They also fear the future because they grieve over the fact who will take care of the grandchildren when they are older or missing (Grinstead et al., 2003; Williamson et al., 2003).

In this session a presentation on the Statute of the Elderly or senior citizen laws, and on topics covered by them during the previous sessions in order to answer their doubts and questions. The topics were: depression, dyslexia, epilepsy, hyperactivity, childhood obesity and addiction, especially alcoholism.

"It was great because I just knew my rights of tickets. I did not even know that there was a Statute of Elderly with these laws. Now, I can pass on to others."

8th session: Intervention evaluation by participants:

First, BAI and BDI were individually reapplied. A final interview was also made on 
the evaluation of the experience and how they felt about the intervention. Subsequently, an evaluation of the group was made on the intervention and its consequences.

It's worth noting that in recent sessions the team realized the changes that were occurring in the grandparents, evidenced in the fact that they took care of appearance, showed more smiling faces and communicative skills, and established friendships with each other. Finally, a fellowship was made with all participants, staff and groups.

"Today, after our meetings here, I feel much better. I have more desire to go out, dressing up, talking to my grandson, but also respect that his mother is his mother. $1 \mathrm{~m}$ someone else. $1 \mathrm{~m}$ not the one who came here at first."

"I will miss this a lot. These lectures have changed me. Not everything is supposed to be my way. And many aspects have changed because I just thought of my way. But he also has opinions and feelings. You have to learn to talk. I teach every little thing I learned here at home."

"I felt much better. I am shy and it helped me. It was a gift in my life."

\section{Conclusion}

The reasons that make grandparents raise their grandchildren are permeated by the following facts: the separation of the child's parents; the children have lived with them when they became parents; parents work; financial problems or negligence on the part of parents. While some grandparents have said they were happy to be raising their grandchildren, most said they felt tired and worried about this situation, reaching the will that the parents would take responsibility for their own children. Due to the proximity of the houses, or even the movement of grandchildren between the homes of parents and grandparents (or other relatives), it was difficult to identify whether the grandparents took care alone or not of the grandchildren. This is a condition that needs to be investigated in the future since it is differently for grandparents to take care alone for their grandchildren or to count on the help from others.

Despite the difficulties encountered in the research, such as the lack of some grandparents because of other commitments and the difficulty in transportation, it can be concluded that the intervention had a positive effect on grandparents to minimize anxiety and/or depression experienced by them. It was possible to verify the effects of the intervention and the context that was afforded to grandparents (leaving home, know other people, to be heard with respect and empathy) to ease the situation in which several of them were.

Initially the project was designed to work with control and experimental groups, but unfortunately it was not possible to match the number of participating grandparents in the control group with the experimental group, which contributed to the decision to continue with the research only with experimental groups. The chances rise that this absence was caused by lack of interest, involvement in other activities or the long waiting time (two and a half months) that grandparents experienced in the control group until they were called, leading to demotivation.

It is considered that this research has made an initial proposal for intervention, but it 
is hoped that it can be improved, adapted and applied by other professionals and researchers in order to offer support to those grandparents who both contribute to society, but are not yet duly recognized and cared for.

\section{References}

Aratangy, L. R., \& Posternack, L. (2005). Livro dos avós: Na casa dos avós é sempre domingo? (The Book of Grandparents: At Grandparents Home Is It Always Sunday?) São Paulo: Artemeios.

Attala, M. M. A. (1996). O olhar das avós: Vivência de avós que cuidam de seus netos (The View of Grandmothers: The Experience of Grandmothers Who Take Care of Their Grandchildren). Dissertação de Mestrado, Instituto de Psicologia, Universidade de São Paulo.

Baptista, M. N., Souza, M. S., \& Alves, G. A. S. S. (2008). Evidências de validade entre a Escala de Depressão (EDEP), o BDI e o Inventário de Percepção de Suporte Familiar (IPSF) (Evidences of Validity between the Depression Scale (EDEP), Beck Depression Inventory (BDI) and Inventory of Family Support Perception). Psico-USF, 13, 211-220.

http://dx.doi.org/10.1590/S1413-82712008000200008

Cardoso, A. R., \& Brito, L. M. T. (2014). Ser avó na família contemporânea: Que jeito é esse? (Being a Grandmother in the Contemporary Family: How Is This?) Psico-USF, Bragança Paulista, 19, 433-441. http://dx.doi.org/10.1590/1413-82712014019003006

Cardoso, A. R. (2011). Avós do século XXI: Mutações e rearranjos na família contemporânea (Grandmothers of the 21st Century: Mutation and Rearrengements of the Contemporary Family). Curitiba: Juruá Editora.

Cunha, J. A (2001). Manual da versão em português das Escalas de Beck (Manual of the Portuguese Version of Beck's Scales). São Paulo: Casa do Psicólogo.

Dias, C. M. S. B., \& Costa, J. M. (2006). Um estudo sobre avós guardiãs na cidade do Recife (A Study of Guardian Grandmothers in the City of Recife). In M. C. L. A. Amazonas, A. O. Lima, \& C. M. S. B. Dias (Orgs), Mulher e Famílias: Diversos dizeres (Woman and Families: Vários Sayings) (pp. 127-138). São Paulo: Oficina do Livro.

Dias, C. M. S. B., Ataíde, E. R., Albuquerque, N. C., \& Magalhães, K. A. (2011). As relações entre as gerações nas famílias chefiadas por idosos (The Relations between the Generations in Families Headed by Elderly). In T. Féres-Carneiro (Org.), Casal e família, conjugalidade, parentalidade e psicoterapia (Couple, Family, Marital and Parental Psychotherapy) (pp. 79-94). São Paulo: Casa do Psicólogo.

Dias, C. M. S. B., Costa, J. M., \& Rangel, V. A. (2005). Avós que criam seus netos: Circunstâncias e consequências (Grnadmothers Who Take Care of Their Grandchildren: Circumstances and Consequences) (pp. 158-176). In T. Féres-Carneiro (Org.), Família e casal: Efeitos da contemporaneidade (Family and Couple: Effects of the Contemporaneity). Rio de Janeiro: PUC-Rio.

Fitzgerald, M. L. (2001). Grandparent Parents: Intergenerational Surrogate Parenting. Journal of Holistic Nursing,19, 297-307. http://dx.doi.org/10.1177/089801010101900309

Goreinstein, C., \& Andrade, L. (1998). Inventário de Depressão de Beck: Propriedades psicométricas da versão em português (Beck's Inventory of Depression: Psychometric Properties of the Portuguese Version). Revista de Psiquiatria Clínica, 25.

Grinstead, L. N., Leder, S., Jensen, S., \& Bond, L. (2003). Review of Research on the Health of Caregiving Grandparents. Journal of Advanced Nursing, 44, 318-326.

http://dx.doi.org/10.1046/j.1365-2648.2003.02807.x

Heywood, M. E. (1999). Custodial Grandparents and Their Grandchildren. The Family Journal: 
Counseling and Therapy for Couples and Families, 7, 367-372.

http://dx.doi.org/10.1177/1066480799074007

Instituto Brasileiro de Geografia e Estatística (IBGE)-Brazilian Institute of Geography and Statistics) (2010). Sinopse do Censo Demográfico 2010.

http://www.ibge.gov.br/home/presidencia/noticias/noticia_visualiza.php?id_noticia=1866\&i_p agina $=1$

Jendrek, M. P. (1994). Grandparents Who Parent Their Grandchildren: Circumstances and Decisions. The Gerontologist, 34, 206-216. http://dx.doi.org/10.1093/geront/34.2.206

Kelley, S. J., Whitley, D., Sipe, T. A., \& Yorker, B. C. (2000). Psychological Distress in Grandmother Kinship Care Providers: The Role of Resources, Social Support and Physical Health. Child Abuse \& Neglect, 24, 311-321. http://dx.doi.org/10.1016/S0145-2134(99)00146-5

Lopes, L. O., \& Cachioni, M. (2013). Impacto de uma intervenção psicoeducacional sobre o bemestar subjetivo de cuidadores de idosos com doença de Alzheimer (The Imapct of a Psychoeducational Intervention in the Subjective Well-Being of Caregivers of Elderly with Alzheimer). Ribeirão Preto. Temas em Psicologia, 21, 165-181.

http://dx.doi.org/10.9788/TP2013.1-12

Lucchiari, H. P. S. (1999). Planejamento por encontros (Planning by Meetings). Porto Alegre: Artmed.

Mainetti, A. C., \& Wanderbrooke, A. C. N. S. (2013). Avós que assumem a criação de netos (Grandparents Who Assume the Raising of Grandchildren). Pensando Famílias, 17, 1-8.

Mayer, M. (2002). Grandparents Rearing Grandchildren: Circunstances and Interventions. School Psychology International, 23, 371-385. http://dx.doi.org/10.1177/0143034302234001

Minayo, M. (2004). Pesquisa social: Teoria, método e criatividade [Social Research: Theory, Methods and Criativity]. Rio de Janeiro: Vozes.

Morales, A. G. (2001). The Slave Grandmother Syndrome. Pandemia del siglo XXI. Grupo Edit. Granada: Universitario. Http://personales.jet.es/aguijarro/abuela

Morgado, S., \& Vitorino, A. (2012). Envelhecimento positivo ao serviço dos netos [Aging Positively to the Service of the Grandchildren]. Revista INFAD de Psicologia (International Journal of Developmental and Educational Psychology), 2, 13-24.

Musil, C. M., \& Ahmad, M. (2002). Health of Grandmothers: A Comparison by Cargiver Status. Journal of Aging and Health, 14, 96-121. http://dx.doi.org/10.1177/089826430201400106

Oliveira, P. S. (1993). Vidas compartilhadas: o Universo cultural das relações avós e netos [Shared Lives: The Cultural Universe of the Relationship of Grandparents and Grandchildren]. Tese de Doutorado, São Paulo: Instituo de Psicologia da Universidade de São Paulo.

Orb, A., \& Davey, M. (2005). Grandparents Parenting Their Grandchildren. Australian Journal on Aging, 24, 162-168. http://dx.doi.org/10.1111/j.1741-6612.2005.00114.x

Pebley, A. R., \& Rudkin, L.L. (1999). Grandparents Caring for Grandchildren: What Do We Know? Journal of Family Issues, 20, 218-242. http://dx.doi.org/10.1177/019251399020002003

Quintão, S., Delgado, A. R., \& Prieto, G. (2013). Validity Study of the Beck Anxiety Inventory (Portuguese Version) by the Rasch Rating Scale Model. Psicologia: Reflexão e Crítica, 26, 305310. http://dx.doi.org/10.1590/S0102-79722013000200010

Strom, R. D., \& Strom, S. K. (1987). Preparing Grandparents for a New Role. The Journal of Applied Gerontology, 6, 476-486. http://dx.doi.org/10.1177/073346488700600409

Strom, R. D., \& Strom, S. K. (1993). Grandparent Education: Improving Communication Skills. Educational Gerontology, 19, 717-725. http://dx.doi.org/10.1080/0360127930190803

Strom, R. D. (1988). Intergenerational Learning and Curriculum Development. Educational 
Gerontology, 14, 165-181. http://dx.doi.org/10.1080/0380127880140301

Stuart-Hamilton, I. (2002). A psicologia do envelhecimento: Uma introdução [The Psychology of Aging: An Ntroduction]. Porto Alegre: Artmed.

Triadó, C., Martinez, G., \& Villar, F. (2000). El rol y la importancia de losabuelos para susnietos adolescents [The Role and Importance of the Grandparents for the Teenage Grandchildren]. Anuario de Psicologia, 31, 107-118.

Williamson, J., Softas-Nall, B., \& Miller, J. (2003). Grandmothers Raising Grandchildren: An Exploration of Their Experiences and Emotions. The Family Journal, 11, 23-32. http://dx.doi.org/10.1177/1066480702238468

Submit or recommend next manuscript to SCIRP and we will provide best service for you:

Accepting pre-submission inquiries through Email, Facebook, LinkedIn, Twitter, etc. A wide selection of journals (inclusive of 9 subjects, more than 200 journals)

Providing 24-hour high-quality service

User-friendly online submission system

Fair and swift peer-review system

Efficient typesetting and proofreading procedure

Display of the result of downloads and visits, as well as the number of cited articles

Maximum dissemination of your research work

Submit your manuscript at: http://papersubmission.scirp.org/

Or contact psych@scirp.org 